\title{
Motivasi Belajar Mahasiswa Terhadap Metode Pembelajaran Online iLearning+ Pada Perguruan Tinggi
}

\section{Student Learning Motivation Against iLearning + Online Learning Method in Higher Education}

\author{
Untung Rahardja $^{\text {(), Ninda Lutfiani }}{ }^{2)}$, Indri Handayani ${ }^{3)}$, Fitria Marwati Suryaman ${ }^{4)}$ \\ Universitas Raharja \\ Jl. Jenderal Sudirman No. 40, Cikokol Tangerang, (021) 5529692 \\ e-mail: ${ }^{1}$ untung@raharja.info, ${ }^{2}$ ninda@raharja.info, ${ }^{3}$ indri@ raharja.info, \\ ${ }^{4}$ fitria.marwati@raharja.info
}

\begin{abstract}
Abstrak
Pendidikan merupakan kebutuhan manusia yang harus selalu berkembang sesuai dengan perubahan zaman yang ada. Perkembangan yang semakin pesat di dunia pendidikan dan teknologi sangat menjadi acuan untuk kualitas pendidikan yang ada di Indonesia. Sistem pembelajaran online adalah satu-satunya media pembelajaran yang dapat memudahkan bagi siapa saja yang ingin melanjutkan ke jenjang Diploma ataupun Sarjana tanpa harus bersusah payah datang ke tempat proses pembelajaran berlangsung. Banyaknya Universitas ataupun Perguruan Tinggi sudah menerapkan sistem belajar online bagi peserta didik yang terhalang oleh suatu pekerjaan atau sebagainya. Penelitian ini bertujuan untuk meningkatkan motivasi belajar mahasiswa dalam sistem belajar online. Pembelajaran online yang sudah diterapkan di Perguruan Tinggi Raharja disebut dengan idu.ilearning.co atau sering disebut iLearning+, namun pembelajaran online tersebut masih kurang maksimal dimana mahasiswa yang tidak memiliki motivasi belajar menjadi permasalahan yang harus dipecahkan. Metode yang digunakan dalam penelitian ini adalah mind mapping dan literature review. Dengan adanya penghargaan berupa nilai tambahan membuat motivasi dalam belajar menjadi meningkat. Sehingga dapat disimpulkan bahwa adanya penghargaan berupa nilai tambahan bagi mahasiswa yang aktif menjadi pemacu semangat belajar mahasiswa menjadi bertambah.
\end{abstract}

Kata kunci-Pembelajaran Online, iLearning, iDu iLP, Motivasi Belajar

\begin{abstract}
Education is a human need that must always develop according to the changing times. The increasingly rapid development in the world of education and technology has become a reference for the quality of education in Indonesia. The online learning system is the only learning media that can make it easier for anyone who wants to pursue Diploma or Bachelor level without having to go to the place of the learning process. The number of universities or colleges has implemented an online learning system for students who are hindered by a job or so on. This study aims to improve student learning motivation in online learning systems. Online learning that has been applied at Raharja College is called idu.ilearning.co or often called iLearning +, but online learning is still not optimal where students who do not have learning motivation become a problem that must be solved. The method used in this study is mind mapping and literature review. With the award in the form of additional value, motivation in learning becomes increased. So that it can be concluded that the existence of an award in the
\end{abstract}


form of additional value for students who are active made by lecturers becomes a driver of student spirit of learning to increase.

Keywords - Online Learning, iLearning, iDu iLP, Motivation To Learn

\section{PENDAHULUAN}

Pendidikan merupakan kebutuhan manusia yang harus selalu berkembang sesuai dengan perubahan zaman yang ada. Perkembangan yang semakin pesat di dunia pendidikan dan teknologi sangat menjadi acuan untuk kualitas pendidikan yang ada di Indonesia. Perkembangan ini berlangsung secara cepat dan terus menerus sehingga membuat Kementerian Pendidikan Nasional (Kemdiknas) menekankan pada penyelenggara layanan prima pendidikan nasional untuk membentuk insan Indonesia cerdas komprehensif. Setiap inovasi diciptakan untuk memberikan manfaat positif bagi kehidupan manusia[1]. Pendidikan yang berhasil akan menciptakan manusia yang pantas dan berkelayakan di masyarakat sehingga menjadi penting pendidikan untuk mencetak manusia yang memiliki berkualitas dan berdaya saing[2]. Dalam visi tersebut dapat dikatakan jika pembelajaran online adalah satu-satunya media pembelajaran yang dapat memudahkan bagi siapa saja yang ingin melanjutkan ke jenjang Diploma ataupun Sarjana tanpa harus bersusah payah datang ke tempat proses pembelajaran berlangsung. Bentuk dari perkembangan teknologi informasi yang diterapkan didunia pendidikan adalah iLearning.

iLearning merupakan sebuah inovasi yang mempunyai kontribusi sangat besar terhadap perubahan proses pembelajaran, dimana proses belajar tidak lagi hanya mendengarkan uraian materi dari guru tetapi siswa juga melakukan aktivitas lain seperti mengamati, melakukan, mendemonstrasikan dan lain-lain. Materi bahan ajar dapat divisualisasikan dalam berbagai format dan bentuk yang lebih dinamis dan interaktif sehingga learner atau murid akan termotivasi untuk terlibat lebih jauh dalam proses pembelajaran tersebut[3]. Perguruan Tinggi Raharja sudah menerapkan metode sistem pembelajaran online yang disebut dengan idu.ilearning.co atau dikenal dengan iLearning +. iLearning + merupakan pembelajaran yang fleksibilitas dan dapat menghemat waktu, biaya dan tenaga[4]. Sistem pembelajaran online ini terdapat materi yang dipelajari dan tugas yang harus dikerjakan oleh setiap mahasiswa. iLearning merupakan metodologi pembelajaran modern yang mengintegrasikan perpaduan antara belajar, bermain, berdoa dan bekerja. Dengan dipadukan unsur 4B tersebut, fungsi otak kanan dan otak kiri bekerja bersinergi. Dalam metode pembelajaran iLearning ini membutuhkan media pendukung sebagai jembatan antara dosen dan mahasiswa dalam penyampaian materi bahan ajar perkuliahan[5]. Sistem ini mempermudah memahami materi yang disampaikan beserta semua penjelasannya[6]. Karena iLearning dikemas dengan sedemikian rupa dengan konten-konten pendukung[7].

Terdapat satu masalah yang harus dipecahkan yaitu kurang adanya motivasi belajar mahasiswa dalam menjalankan pembelajaran online tersebut dan tujuan penelitian ini adalah untuk meningkatkan motivasi belajar mahasiswa pada sistem belajar online iLearning Plus. Motivasi merupakan salah satu determinan penting dalam proses pembelajaran. Motivasi dalam belajar berperan dalam menumbuhkan gairah, merasa senang dan semangat untuk belajar[8]. Menurut Bomia Motivasi belajar merujuk pada kemauan, kebutuhan, keinginan dan keharusan siswa untuk ikut berpartisipasi dan berhasil dalam proses pembelajaran[9]. Pemberian penghargaan seperti nilai tambahan atau yang sering disebut Special Contribution (SC) yang diberikan oleh dosen bagi mahasiswa yang aktif di milis kelas dan selalu mengerjakan tugas merupakan hadiah kecil yang cukup efektif untuk menumbuhkan semangat belajar mahasiswa. Walaupun memang banyak dari mahasiswa tidak peduli dengan nilai tambahan tersebut, ada kalanya mereka menjadi tertantang untuk mendapatkan nilai tambahan atau Special Contribution (SC) dikarenakan hal tersebut bisa menjadi acuan mereka untuk menunjukan potensi yang dimilikinya. Sehingga mahasiswa yang paling banyak mendapatkan nilai tambahan dapat memotivasi mahasiswa yang lainnya dalam berlombalomba untuk mendapatkan nilai Special Contribution (SC) tersebut[10]. Dan dengan itu perlu 
adanya peningkatan bersama dalam metode pembelajaran, komunikasi dan interaksi antara siswa dan guru yang memudahkan aktivitas berbagi (sharing) sumber pembelajaran dan aktivitas diskusi tanpa terhalang oleh waktu dan ruang[11].

\section{METODE PENELITIAN}

Dalam melakukan penelitian ini ada 2 (dua) tahapan metodologi yaitu sebagai berikut:

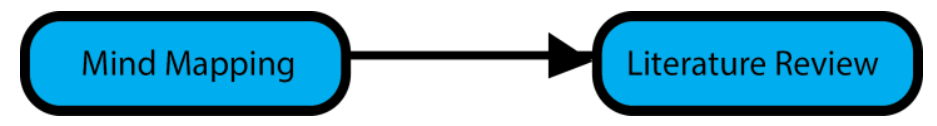

\section{Metode Penelitian}

\section{Gambar}

\subsection{Metode Mind Mapping}

Mind Mapping atau peta pikiran adalah metode mempelajari konsep yang ditemukan oleh Tony Buzan seorang kepala Brain Foundation tahun 1970. Konsep ini didasarkan pada cara kerja otak kita menyimpan informasi atau dapat disebut sebuah teknik pencatatan yang didasarkan pada riset tentang cara otak yang sebenarnya. Cara ini adalah cara yang paling kreatif dan efektif dalam membuat catatan sehingga dapat dikatakan mind mapping benar-benar memetakan pikiran orang yang membuatnya Pandley[12]. Model pembelajaran mind mapping merupakan strategi pembelajaran yang dapat mendorong meningkatkan hasil belajar[13]. Tahapan metode mind mapping yang digunakan pada penelitian ini dapat dilihat pada gambar 2 .

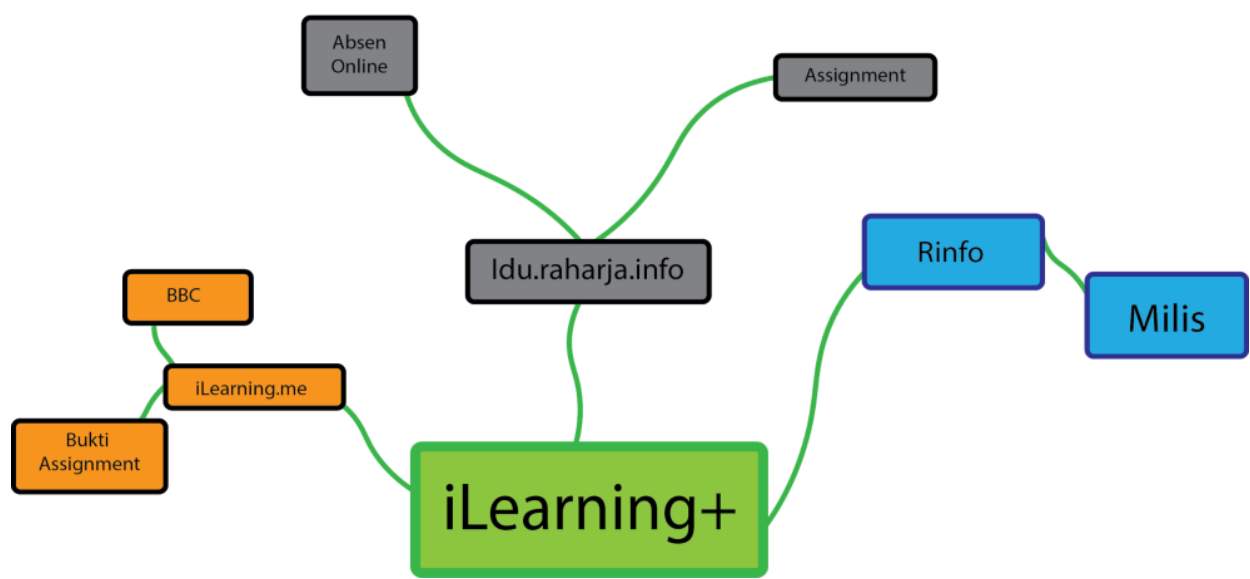

Gambar 2 . Tahapan Metode Penelitian Mind Mapping

Terdapat 4 (empat) platform yang digunakan dalam metode pembelajaran iLearning+:

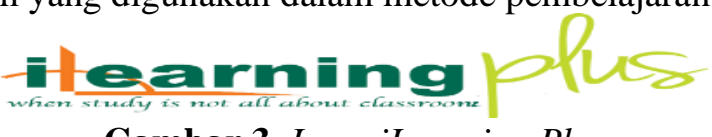

Keterangan:

Gambar 3. Logo iLearning Plus

a. Mencari permasalahan yang terjadi lalu menentukan tema yang akan diambil yaitu pembelajaran online iLearning+. 
b. Motivasi belajar online mahasiswa dapat dipantau oleh dosen melalui email Rinfo yaitu milis. Dari sana dosen dapat melihat siapa saja mahasiswa yang paling aktif di milis setiap minggunya.

c. Motivasi belajar online juga dapat dipantau oleh dosen dari idu.ilearning.info melalui tugas assignment yang diberikan dosen dan absen online yang ada di sistem belajar online tersebut.

d. Tidak hanya itu motivasi belajar online juga dapat dipantau dosen melalui ilearning.me atau IME dari BBC (Buka Baca Comment) dan atau melalui bukti assignment yang dikerjakan.

\subsection{Metode Literature Review}

Literature Review merupakan bahan teori yang menguraikan sebuah penelitian untuk dijadikan landasan untuk menyelesaikan berbagai rumusan masalah didalam penelitian yang dapat diperoleh dari berbagai sumber yaitu (jurnal,buku,website, dll), banyak penelitian yang sebelumnya dilakukan penelitian ini memiliki akselerasi yang sejalan dari beberapa sumber pustaka dan penelitian yang telah dilakukan[14].

Berdasarkan kesimpulan yang didapatkan, motivasi belajar mahasiswa lebih terlihat ketika berada di milis kelas. Karena dosen dapat dengan mudah sekali melihat grafik atau tinjauan keaktifan mahasiswa yang ada disana melalui fitur-fitur yang ada di dalamnya. Ada 7 (tujuh) literature review yang terdapat dibawah ini:

a. Pada penelitian ini membahas mengenai metode pembelajaran yang baru guna proses belajar mengajar menjadi lebih efektif dan dapat terus dikembangkan, terdapatnya gamifikasi dalam pembelajaran online berguna memacu mahasiswa menjadi lebih semangat juga menjadi sebuah alternatif dalam mengorganisasi dan mengkondisikan situasi belajar agar lebih menarik dan tidak monoton, sehingga dapat menyenangkan dan membangun karakter bagi mahasiswa dalam mengikuti perkuliahan online, terdapatnya leaderboard yang berupa level keaktifan mahasiswa, juga berguna untuk mengetahui seberapa aktif mahasiswa dalam mengerjakan tugas maupun memahami materi perkuliahan yang sudah diberikan oleh dosen. Tahapan-tahapan yang digunakan pada penelitian ini adalah metode observasi dan literature review[10]

b. Tahapan-tahapan yang digunakan dalam penelitian ini adalah Literature review. Pada penelitian ini membahas tentang Rinfo. Rinfo ini adalah Gmail, yang di adaptasi dari Google Platform dengan ciri khas raharja.info sebagai domainnya. Rinfo ini adalah media komunikasi sekaligus alat pendukung dalam proses pembelajaran di Perguruan Tinggi Raharja. Karena selain terintegrasi dengan TPi, Rinfo ini pun terhubung pula dengan alat penunjang pembelajaran lainnya, seperti Docs, Drive, Sites, dan alat penunjang lainnya[15].

c. Tahapan-tahapan yang digunakan dalam penelitian ini adalah decission tree algoritma C.45. Pada penelitian ini membahas tentang menginformasikan kepada mahasiswa untuk antisipasi dini dalam mengikuti perkuliahan agar mendapatkan hasil belajar yang maksimal[16].

d. Tahapan-tahapan dalam penelitian ini menggunakan metode kuantitatif. Penelitian ini membahas tentang terdapat hubungan yang signifikan bermain game online dengan prestasi belajar siswa. Hasil analisis diperoleh nilai koefisien regresi untuk variabel bermain game online bernilai negatif yang menunjukkan bahwa game online berpengaruh negatif terhadap hasil belajar siswa. Permainan game online ada keterkaitan dengan prestasi belajar siswa. Game online tentu saja memberikan dampak candu pada siswa, sehingga mereka melupakan tugas mereka yang utama yaitu belajar. Akibatnya dari segi akademik mereka akan mengalami penurunan prestasi belajar[17].

e. Tahapan-tahapan dalam penelitian ini adalah metode eksperimen. Penelitian ini membahas tentang Motivasi belajar dapat timbul karena dua faktor yaitu faktor intrinsik, berupa hasrat dan keinginan berhasil, dorongan dan kebutuhan belajar, dan harapan akan citacita, sedangkan faktor Surahmadi, B. / Unnes Science Education Journal 5 (1) (2016) 1126 ekstrinsiknya adalah adanya penghargaan, lingkungan belajar yang kondusif, serta 
kegiatan belajar yang menarik. Kedua faktor tersebut disebabkan oleh rangsangan tertentu sehingga seseorang berkeinginan untuk melakukan aktivitas belajar yang lebih giat dan lebih bersemangat[18].

f. Tahapan-tahapan dalam penelitian ini menggunakan metode pengembangan. Penelitian ini membahas tentang media pembelajaran berbasis website pada mata pelajaran pemasaran online layak untuk digunakan sebagai media pembelajaran di sekolah[19].

g. Tahapan-tahapan dalam penelitian ini menggunakan metode eksperimen. Penelitian ini membahas tentang pengaruh penerapan model pembelajaran kooperatif ketik tim permainan turnamen (TGT) dalam pembelajaran sains untuk motivasi belajar keempat siswa kelas SDN Kelapa Dua 06 Pagi Jakarta Barat. Populasi dalam penelitian ini berjumlah 52 orang. Sampel penelitian ini terdiri dari dua kelompok, yaitu kelompok eksperimen 26 orang dan kelompok percobaan 27 orang. Pengambilan sampel ditentukan dengan teknik purposive sampling[20].

\section{HASIL DAN PEMBAHASAN}

Terdapat 2 (Dua) perbedaan pada penelitian ini dengan penelitian yang telah diuraikan diatas. Perbedaan pertama yaitu penelitian ini memanfaatkan nilai tambahan atau yang biasa disebut Special Contribution (SC) untuk meningkatkan motivasi belajar mahasiswa menjadi meningkat sedangkan dari dua penelitian diatas menggunakan mailings group dan website sebagai media motivasi belajarnya. Perbedaan kedua yaitu nilai tambahan atau Special Contribution (SC) bisa menjadi sarana untuk pengembangan diri mahasiswa terlihat dengan jelas dibandingkan menggunakan mailings group dan website.

Special Contribution (SC) adalah nilai tambahan yang biasa diberikan oleh dosen pada mata kuliah yang sedang di ampuhnya sebagai apresiasi kecil untuk mahasiswanya yang aktif agar menjadi acuan semangat belajarnya dan memberikan dampak positif untuk temantemannya yang lain. Tatkala mahasiswa yang tidak peduli dengan nilai tersebut, menjadi tertantang untuk menunjukkan potensi yang dimiliki oleh dirinya. Karena adanya Special Contribution (SC) merupakan satu-satunya tolak ukur untuk mengeksplor dirinya menjadi lebih berkembang dari sebelumnya.

Telah diakui bahwa sebenarnya dengan adanya apresiasi berupa Special Contribution $(S C)$ tersebut, menjadi daya tarik mahasiswa yang malas belajar menjadi mempunyai semangat untuk belajar. Karena dengan adanya pemberian Spesial Contribution (SC) menjadi pecutan bagi mereka sendiri untuk selalu bersemangat mengerjakan tugas-tugas atau pertanyaan yang diajukan oleh dosen tersebut. Dan pada akhirnya tanpa mereka sadari rasa malas itu hilang dengan sendirinya seiring berjalannya waktu.

Dengan Special Contribution (SC) dosen juga dapat melihat dengan jelas keaktifan mahasiswa yang berkembang dan tidak. Manfaat lain selain untuk sarana pengembangan diri mahasiswa, Special Contribution (SC) juga dapat menjadi pemacu semangat belajar yang paling efektif untuk mahasiswa yang malas belajar menjadi sangat bergairah untuk belajar di mata kuliah yang sedang di ampuhnya.

Adapun media pembelajaran iLearning Plus yang juga dapat menjadi pemantauan dosen untuk melihat keaktifan mahasiswa dalam mengerjakan tugas yang sudah diberikan pada iDu. Berikut adalah flowchart Login pada iDu iLP: 


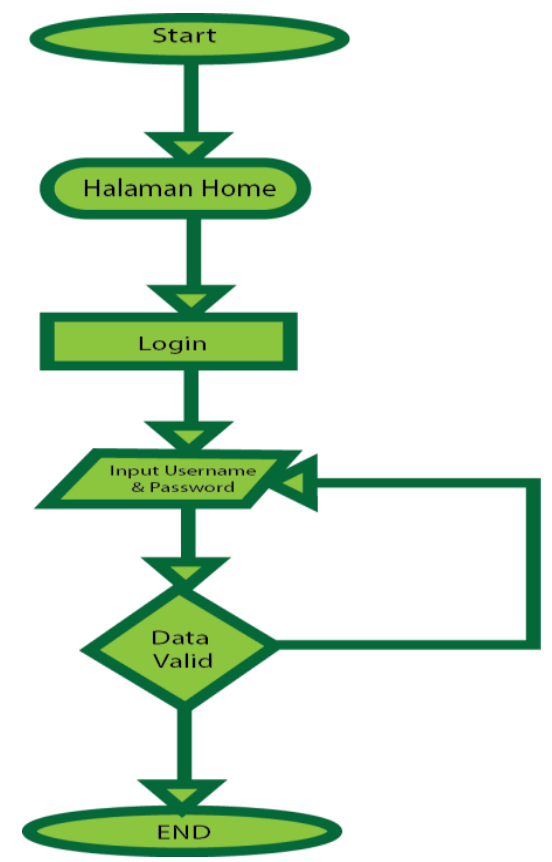

Gambar 4 . Flowchart Login iDu iLP

Gambar di atas menjabarkan process login melalui iDu iLp menggunakan iDu (iLearning Education). Langkah pertama adalah mengunjungi halaman home http://idu.ilearning.co/ lalu pilih login. Kemudian memasukan username dan password dan bisa juga menggunakan SSO (Single sign on)[14].

Mahasiswa dapat membuka materi pembelajaran dan melihat tugas-tugas yang diberikan oleh dosen pada tab home iLP tersebut. Dengan begitu, dosen menjadi tahu mana mahasiswa yang rajin mengerjakan tugas atau tidak dengan cara mensubmit jawaban pada assignment yang telah diberikan.

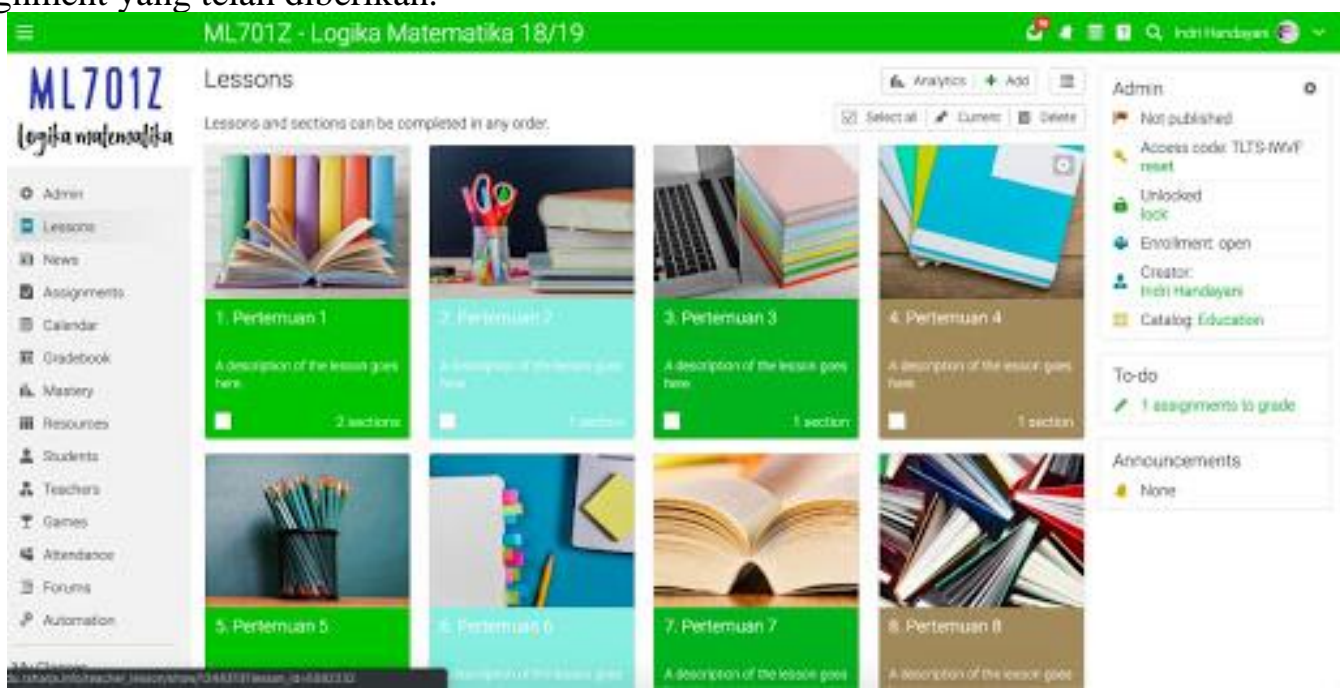

Gambar 5 . Tampilan Materi iLP 
Gambar diatas adalah tampilan materi yang terdapat pada kelas iDu iLearning Plus. Dimana mahasiswa yang tidak mengikuti perkuliahan di kelas sebelumnya dapat mengunduh materi pembelajaran yang ada di menu lesson dikelas yang sedang mereka ampuh. Di dalam materi juga terdapat gambar-gambar, audio dan grafik sesuai dengan materi yang sudah diberikan oleh dosennya.

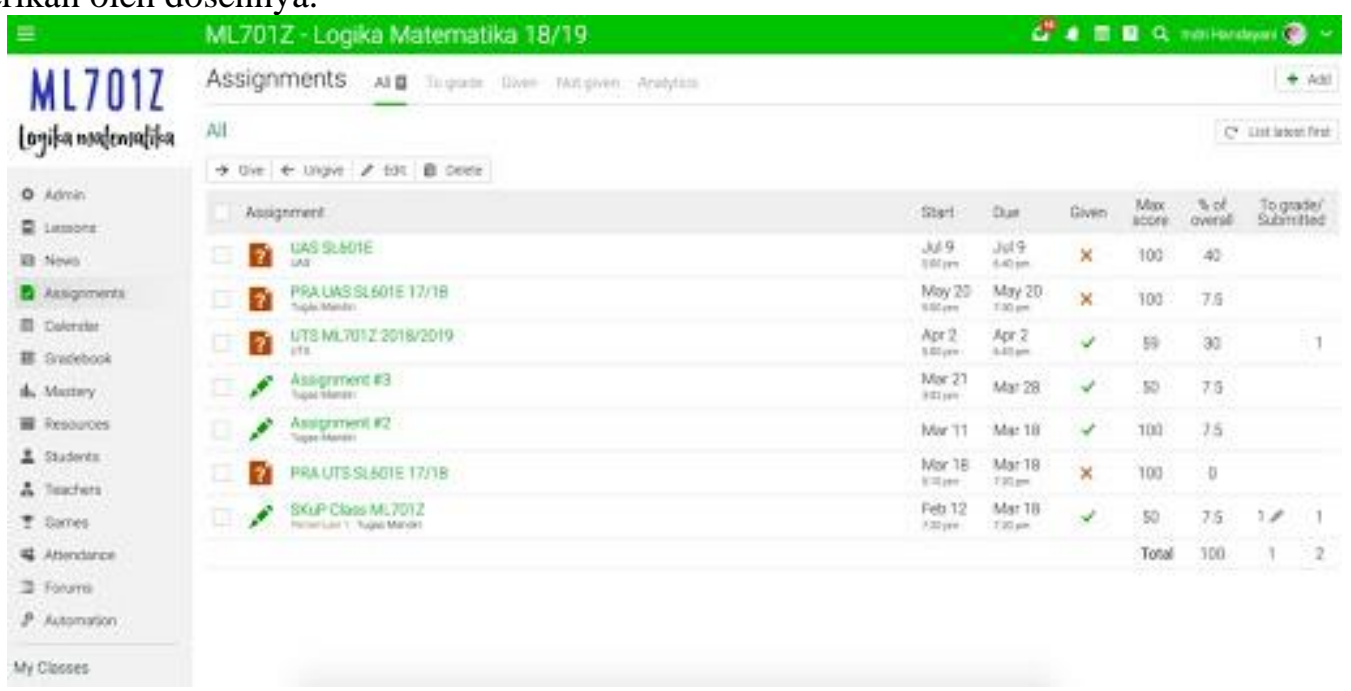

Gambar 6. Tampilan Assignment iLP

Pada tampilan diatas tugas-tugas perkuliahan yang diberikan oleh dosen kepada mahasiswa akan berada seperti pada tampilan diatas dan mahasiswa bisa mengetahui tugas apa saja yang sudah dikerjakan atau yang belum dikerjakan sehingga menjadi overdue atau missing, jadi mahasiswa sudah tidak bisa mengerjakan tugas tersebut dan mendapatkan nilai 0[14]. Dari menu assignment inilah dosen dapat melihat keaktifan mahasiswa dari tugas yang mereka submit tanpa harus bersusah payah datang ke kampus hanya untuk mengumpulkan tugas. Mahasiswa yang paling aktif itulah yang menjadi penilaian dosen untuk mendapat Special Contribution (SC).

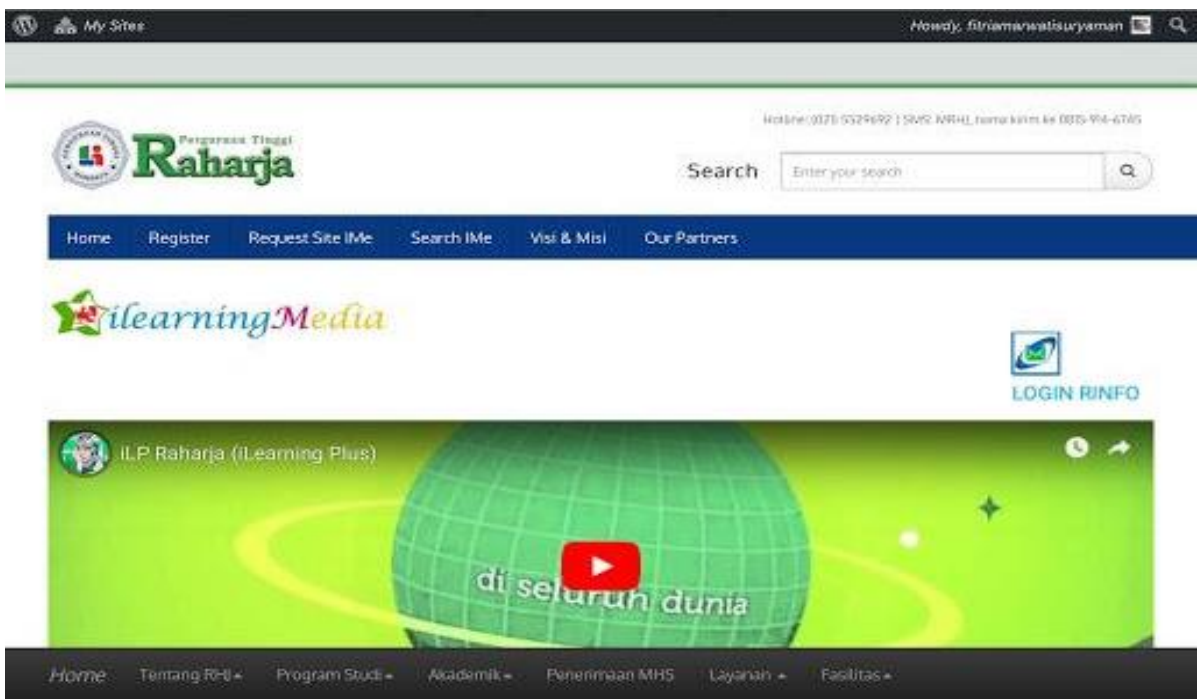

Gambar 7. Tampilan iLearning Me 
iLearning Me adalah media pembelajaran dimana disana mahasiswa dapat mengerjakan tugas secara online. iLearning Me ini adalah platform khusus yang disediakan oleh Perguruan Tinggi Raharja sebagai tempat mahasiswa yang ingin mengerjakan tugas yang telah diberikan pada menu assignment. Tidak hanya itu, di iLearning Me ini juga mahasiswa dapat berdiskusi dengan berkomentar tugas yang mereka kerjakan sudah sesuai atau belum dengan perintah yang diberikan.

Statistik milis ketika belum memakai Special Contribution (SC):

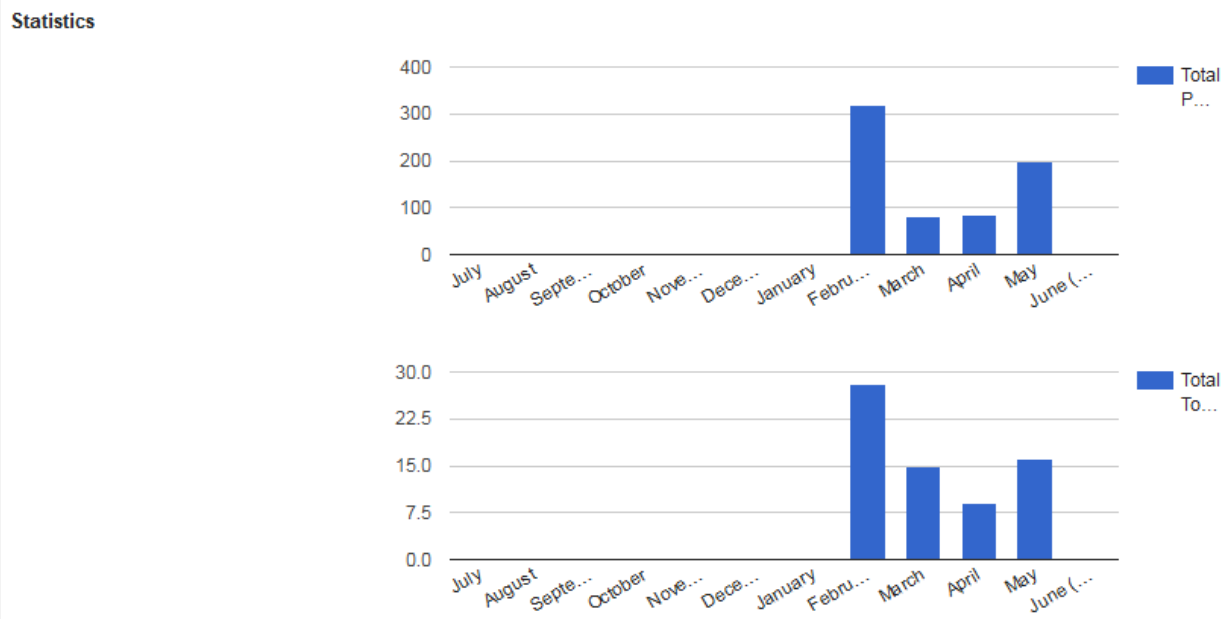

Gambar 8. Tampilan Statistik Sebelum menggunakan Special Contribution (SC)

Statistik ketika sudah menggunakan Special Contribution (SC):

Statistics
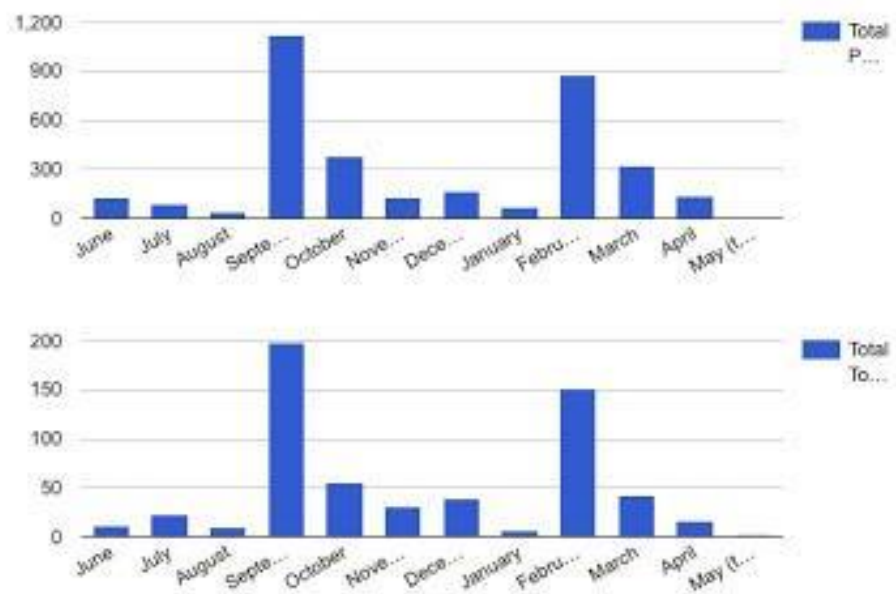

Gambar 9. Tampilan Statistik Sudah Menggunakan Special Contribution (SC)

Dari tampilan statistik diatas dapat disimpulkan bahwa terjadi peningkatan motivasi belajar yang sangat signifikan. Selain itu dosen juga bisa memberikan Special Contribution (SC) kepada mahasiswa yang paling aktif memposting di milis sebagai media berdiskusi mereka dengan dosennya. Mahasiswa yang paling aktif itulah yang menjadi ajang mereka untuk berkompetisi secara sportif dengan memposting pengetahuan atau materi yang sedang mereka 
tempuh. Banyaknya postingan juga bisa di cek di Google System. Berikut adalah tampilan yang dilihat dari banyaknya postingan yang mereka posting untuk berdiskusi:

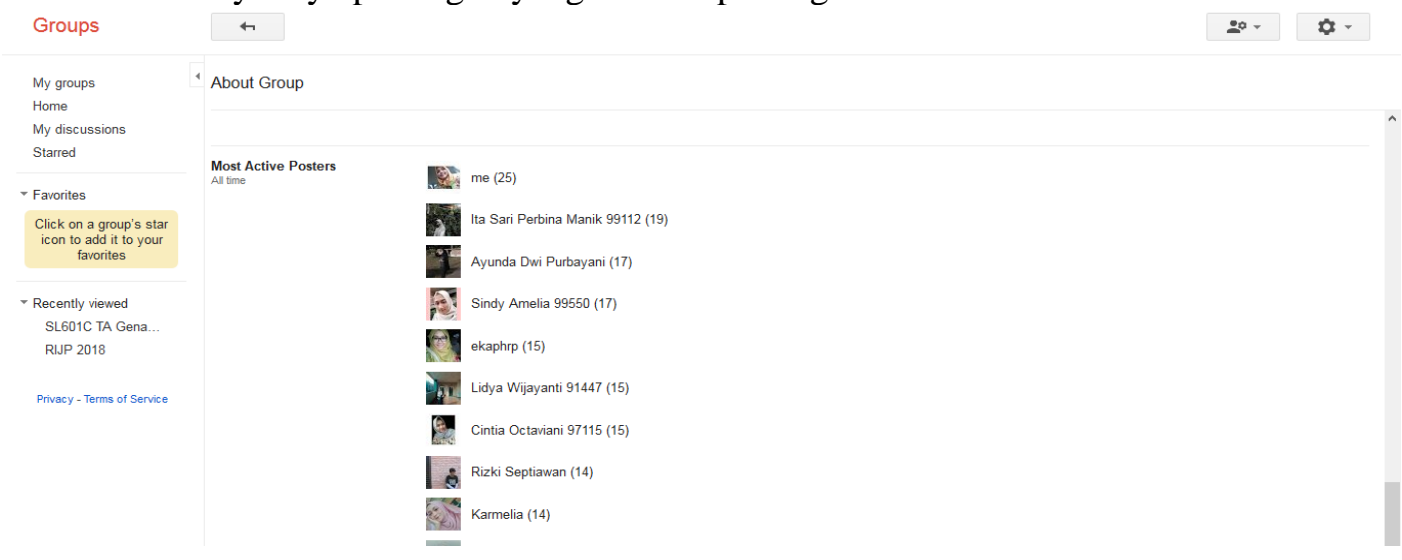

Gambar 10. Tampilan Banyaknya Postingan Milis

Dari sinilah dosen dapat dengan mudah melihat mahasiswa paling aktif di kelasnya, tanpa harus datang ke tempat pembelajaran berlangsung. Dengan begini mahasiswa dapat yang terkendala dengan suatu pekerjaan atau kegiatan lain yang membuatnya tidak bisa datang ke tempat pembelajaran berlangsung dapat turut berkontribusi di kelas yang sedang mereka jalani begitu pula dosen yang dapat sangat mudah melihat semangat belajar mahasiswa tanpa harus bertatap muka. Dan dengan adanya apresiasi sang dosen dengan memberikan Special Contribution $(S C)$ membuatnya terpacu untuk selalu aktif di kelas. Dibawah ini adalah logo atau simbol Special Contribution (SC) yang diberikan oleh mahasiswa yang aktif di kelas:

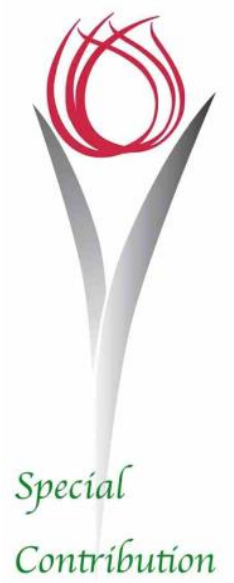

Gambar 11. Logo Special Contribution

\section{KESIMPULAN}

Ada 3 (tiga) kesimpulan yang diperoleh dalam penelitian ini yaitu:

a. Dengan diadakannya Special Contribution (SC) yang diberikan kepada mahasiswa yang paling aktif atau rajin di kelas dapat meningkatkan motivasi mahasiswa untuk aktif di kelas dan akan menularkan energi yang positif kepada teman-temannya sehingga mempunyai semangat untuk belajar. Dengan begitu mahasiswa yang pada awalnya merasa malas belajar pun akhirnya tertular gairahnya untuk memiliki semangat belajar, karena tanpa mereka sadari memperebutkan ekstra point tersebut adalah sebuah tantangan dimana mereka ingin 
menunjukan kreatifitas atau karya yang dimilikinya agar dirinya semakin berkembang dari sebelumnya. Ada berbagai macam cara untuk mahasiswa mendapatkan Special Contribution $(S C)$. Bahkan dengan perlakuan-perlakuan yang tidak terduga pun bisa saja mahasiswa tersebut mendapatkan Special Contribution (SC). Apresiasi kecil yang diberikan itu memang diberikan bagi siapa saja yang ingin berkontribusi lebih.

b. Kemudian sistem pembelajaran online iLearning Plus menjadi maksimal karena adanya semangat mahasiswa untuk mengerjakan tugas-tugas assignment yang diberikan, sehingga keaktifan tersebut akan mempengaruhi nilai yang baik dan dapat mempengaruhi prestasi mahasiswa itu sendiri.

c. Tidak hanya mahasiswa saja yang mendapat nilai terbaiknya. Namun dosen juga patut diberi penghargaan karena dapat membuat mahasiswanya yang pasif menjadi aktif. Tanpa seorang dosen yang memberikan motivasi bagi mahasiswa yang pasif, mahasiswa tersebut mungkin tidak akan tergerak hatinya untuk memaksimalkan kemampuan yang dia punya.

\section{SARAN}

Dalam penelitian ini penulis menyarankan bahwa motivasi intrinsik dan ekstrinsik juga dapat mempengaruhi sistem pembelajaran online. Sehingga penulis berharap untuk penelitian selanjutnya akan membahas tentang motivasi belajar secara intrinsik maupun ekstrinsik. Karena motivasi tidak dari satu arah, melainkan dua arah untuk sama-sama membangun dan menciptakan sesuatu yang lebih baik dari sebelumnya.

\section{UCAPAN TERIMA KASIH}

Ucapan terima kasih penulis kepada Perguruan Tinggi Raharja yang telah memberi dukungan, fasilitas, serta finansial sehingga penulis dapat menyelesaikan penelitian ini dengan baik.

\section{Daftar Pustaka}

[1] Nurdyansyah, N. (2017). Sumber Daya dalam Teknologi Pendidikan. Universitas Muhammadiyah Sidoarjo.

[2] Suprihatin, S. (2015). Upaya guru dalam meningkatkan motivasi belajar siswa. Jurnal Pendidikan Ekonomi UM Metro, 3(1), 73-82.

[3] Aminoto, T. (2014). Penerapan Media E-Learning Berbasis Schoology Untuk Meningkatkan Aktivitas dan Hasil Belajar Materi Usaha dan Energi Di Kelas XI SMA N 10 Kota Jambi. Sainmatika: Jurnal Sains dan Matematika Universitas Jambi, 8(1).

[4] Yusup, M., Aini, Q., \& Pertiwi, K. D. (2016). Media Audio Visual Menggunakan Videoscribe Sebagai Penyajian Informasi Pembelajaran Pada Kelas Sistem Operasi. Technomedia Journal, 1(1), 126-138.

[5] Rahardja, U., Lutfiani, N., Lestari, A. D., \& Manurung, E. B. P. (2019). Inovasi Perguruan Tinggi Raharja Dalam Era Disruptif Menggunakan Metodologi iLearning. Jurnal Ilmiah Teknologi Informasi Asia, 13(1), 23-34.

[6] Kosasi, S. (2015, September). Perancangan E-Learning untuk meningkatkan motivasi belajar guru dan siswa. In Seminar Nasional Pendidikan Teknik Informatika (pp. 1-7).

[7] Rahardja, U., Yusup, M., \& Nurmaliana, A. (2014). Penerapan iLEARNING SURVEY (iSur) dalam Meningkatkan Kualitas Sistem Informasi Selama Proses Pembelajaran Di Perguruan Tinggi raharja. CCIT Journal, 7(3), 335-354.

[8] Fitri, Emria, Ifdil Ifdil, and S. Neviyarni. "Efektivitas layanan informasi dengan menggunakan metode blended learning untuk meningkatkan motivasi belajar." Jurnal Psikologi Pendidikan dan Konseling: Jurnal Kajian Psikologi Pendidikan dan Bimbingan Konseling 2, no. 2 (2016): 84-92. 
[9] Farhan, M., \& Retnawati, H. (2014). Keefektifan PBL dan IBL ditinjau dari prestasi belajar, kemampuan representasi matematis, dan motivasi belajar. Jurnal Riset Pendidikan Matematika, l(2), 227-240.

[10] Rahardja, U., Aini, Q., Ariessanti, H. D., \& Khoirunisa, A. (2018). Pengaruh Gamifikasi pada iDu (iLearning Education) dalam Meningkatkan Motivasi Belajar Mahasiswa. Nusantara Journal of Computers and its Applications, 3(2).

[11] Irawan, Y., Susanti, N., \& Triyanto, W. A. (2015). Analisa dan Perancangan Sistem Pembelajaran Online (E-Learning) Pada SMK Mambaul Falah Kudus. Simetris: Jurnal Teknik Mesin, Elektro dan Ilmu Komputer, 6(2), 345-352.

[12] Darusman, R. (2014). Penerapan metode mind mapping (peta pikiran) untuk meningkatkan kemampuan berpikir kreatif matematik siswa SMP. Infinity Journal, 3(2), 164-173.

[13] Retnowati, T. (2018). Penerapan model pembelajaran tipe mind mapping untuk meningkatkan hasil belajar peserta didik pada mata pelajaran biologi tentang sistem regulasi di kelas XI IPA C SMA Negeri 5 Bogor. Educate: Jurnal Teknologi Pendidikan, $3(1), 1-19$.

[14] Ariessanti, H. D., \& Aini, Q. (2017). Penerapan iDu iLearning Plus berbasis Gamification Sebagai Media Pembelajaran Jarak Jauh pada Perguruan Tinggi. Technomedia Journal, 1(2), 37-49.

[15] Rahardja, U., Tiara, K., \& Wijaya, R. I. T. (2014). Penerapan Rinfo Sebagai Media Pendukung Untuk Proses Pembelajaran Pada Perguruan Tinggi Raharja. CCIT Journal, 8(1), 101-115.

[16] Sembiring, M. A., Sibuea, M. F. L., \& Sapta, A. (2018). Analisa Kinerja Algoritma C. 45 Dalam Memprediksi Hasil Belajar. Journal Of Science and Social Research, 1(1), 73-79.

[17] Nuhan, M. Y. G. (2016). Hubungan Intensitas Bermain Game Online Dengan Prestasi Belajar Siswa Kelas IV Sekolah Dasar Negeri Jarakan Kabupaten Bantul Yogyakarta. BASIC EDUCATION, 5(6), 494-501.

[18] Surahmadi, B. (2016). Pengaruh Media Pembelajaran Virtual Berbasis Quipper School Untuk Meningkatkan Motivasi Belajar dan Hasil belajar Peserta didik Kelas VIII SMP N 1 Temanggung. Unnes Science Education Journal, 5(1).

[19] Darussalam, A. N. D. I. (2015). Pengembangan media pembelajaran berbasis web interaktif (blog) untuk meningkatkan motivasi belajar pada mata pelajaran pemasaran online sub kompetensi dasar merancang website (studi pada siswa kelas $\mathrm{X}$ tata niaga SMK Negeri 2 Nganjuk). Jurnal Pendidikan Tata Niaga (JPTN), 3(2).

[20] Hakim, S. A., \& Syofyan, H. (2018). Pengaruh Model Pembelajaran Kooperatif Tipe Teams Games Tournament (TGT) Terhadap Motivasi Belajar IPA Di Kelas IV SDN Kelapa Dua 06 Pagi Jakarta Barat. International Journal of Elementary Education, 1(4), 249-263. 